\title{
legelivet
}

På disse sidene i Tidsskriftet - legelivet - finner du stoff om legers liv.

Her er det presentasjon av arbeidssteder, nyhetssaker, nye doktorgrader,

nye spesialister, prisutdelinger og minneord.

Alt samlet på ett sted - så du kan følge enda bedre med.

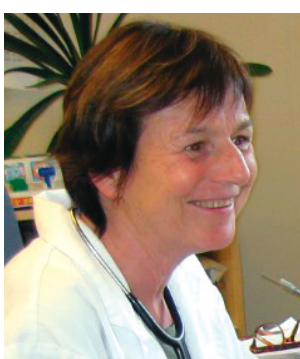

Elisabeth Swensen. Foto: Privat

Elisabeth Swensen (f. 1951) er kommuneoverlege og fastlege ved Seljord helsesenter.

\section{Den hvite frakken}

Klær skaper folk. Jeg har gjenoppdaget legefrakken som nyttig rekvisitt i mitt eget profesjonelle prosjekt.

Hele mitt legeliv, 33 år, har jeg tilbrakt som distriktslege - allmennlege og kommuneoverlege - i Vest-Telemark. Jeg kom som urban eksilant med bakgrunn i 1970-årenes opprør mot det bestående. Legerollen slik vi hadde erfart den i utdanningen, patriarkalsk og hierarkisk definert, fortonte seg overmoden for historiens skraphaug. Jeg hatet eimen av laugsbroderskap og Rotary. Min ambisjon var å bli venn med pasientene, at vi skulle møtes som frie og likeverdige, hva nå det måtte bety. I ettertid kan man jo rødme over sin egen implisitte forutforståelse av at pasientene med andre ord ikke selvsagt var likeverdige.

I 1981 var jeg ny i faget. Ny i rollen. Ny i bygda. Hvordan iscenesette seg selv som «lege for folket»? Av med legefrakken! Se meg som den jeg er - ung kvinne i greie olabukser, gensere fra $\mathrm{H} \& \mathrm{M}$, mammas gamle strikkejakke i januar, T-skjorter om sommeren, en sjelden gang skjørt eller kjole. «Heve du pynta deg?» kunne pasientene spørre da. De fire gangene jeg gikk gravid, kunne alle følge med på magen som vokste, noen pasienter klappet på den. I all vennskapelighet. Det var litt hyggelig - og litt ugreit.

I 2014 er jeg den eldste legen på kontoret vårt. Jeg vet sånt som nesten ingen andre vet om nesten alle i mitt lokalsamfunn, på et eller annet vis. Det er noen år siden jeg tok på meg frakken. Det gikk opp for meg at folk ikke vil at jeg skal bli for synlig som privatperson i rollen som innviet i deres hemmeligheter, tvert imot. Empatisk og personlig, ja, men først og fremst forutsigbar og profesjonell.

Det første jeg gjør om morgenen på jobb er å rusle rundt med kaffekoppen og ta inn stemningen. I sivil. Deretter ifører jeg meg den klassiske hvite legefrakken over mine egne klær - fortsatt olabukse og genser, en sjelden gang skjørt. Jeg er gjenkjennelig uformell, samtidig universell. Kombinasjonen fungerer glimrende for formålet. Det heter avstandsregulering. Jeg bruker frakken helt bevisst som virkemiddel. Oftest har jeg den helt åpen, slik at mine egne klær synes. Noen ganger knepper jeg én enkelt knapp, noen ganger et par, en sjelden gang hele fronten. Bare før jeg henter inn barnepasienter tar jeg frakken konsekvent av, og iblant i situasjoner der det er naturlig for både meg og pasienten å markere en slags unntakstilstand, som når pårørende kommer første gang på kontoret etter et dødsfall.

Pasientenes reaksjoner på legefrakken har vært entydig anerkjennende. Bygdefolket tok i sin tid godt imot meg som den jeg var da. Nå er de nok glade for at legen deres er blitt voksen.

\section{Elisabeth Swensen}

elswense@online.no 